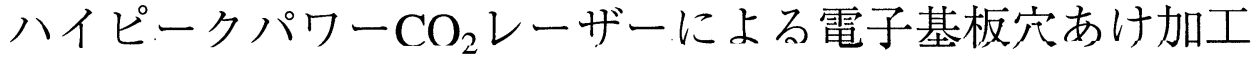

佐藤 行雄, 西前順一, 岩田明彦, 竹野 祥瑞*, 福島 司**, 金岡 優**

三菱電機 (株) 先端技術総合研究所 ( $7661-8661$ 兵庫県尼崎市塚口本町8-1-1)

*三菱電機 (株) 生産技術センター ( ₹ 661-8661 兵庫県尼崎市塚口本町8-1-1)

**三菱電機 $($ 株) 名古屋製作所 (广461-8670 愛知県名古屋市東区矢田南5-1-14)

\section{Micro-Drilling of Advanced Electric Boards with a High-Peak Power $\mathrm{CO}_{2}$ laser}

\author{
Yukio SATO, Juniti NISHIMAE, Akihiko IWATA, Shouzui TAKENO,* \\ Tsukasa FUKUSHIMA, ** and Masaru KANAOKA** \\ Advanced Technology R\&D Center, Mitsubishi Electric Corporation \\ 8-1-1 Tsukaguchi-honmachi, Amagasaki, Hyogo 661-8661 \\ *Manufacturing Engineering Center, Mitsubishi Electric Corporation \\ 8-1-1 Tsukaguchi-honmachi, Amagasaki, Hyogo 661-8661 \\ **Nagoya Works, Mitsubishi Electric Corporation, 5-1-14 Yadaminami, Higashi-ku, Nagoya, Aichi 461-8670
}

(Received September 6, 1999)

\begin{abstract}
Micro-hole drilling of advanced printed boards with a $\mathrm{CO}_{2}$ laser is revealed. The applied high-peak power $\mathrm{CO}_{2}$ laser has a pulse duration shorter than $100 \mu$ s and a peak power level in the $\mathrm{kW}$-range. The design of the laser system and its implementation into a processing system lead to an industrial laser drilling system which is able to process minimum hole diameters of $50 \mu \mathrm{m}$. Some examples of micro-drilling results are described.
\end{abstract}

Key Words: Micro-hole drilling, Advanced printed boards, Pulse $\mathrm{CO}_{2}$ laser, High-peak power $\mathrm{CO}_{2}$ laser, $\mathrm{CO}_{2}$ laser drilling system

\section{1.はじめに}

パソコン, 携帯電話, ハンディビデオ等, 近年の情報通信, 映像機器を中心とした電子機器の急激な小型軽量・高機 能化の進展にともなって, プリント配線基板の高密度化が 不可欠なものとなっている，バイアホールと呼ばれる多 層基板の層間接続穴径に対しても,従来の $\phi 300 \mu \mathrm{m}$ であった ものが最近では $\phi 100 \mu \mathrm{m}$ 程度までに小径化し,さらには $\phi 50 \mu \mathrm{m}$ までの微細穴加工への要求が高まっている.

このような $\phi 100 \mu \mathrm{m}$ 以下の微細な穴開けでは,従来のドリ ルによる方法では対応できず, フォトビア法1)とともに,パ

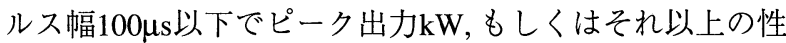
能を有する短パルス, 高ピーク出力 $\mathrm{CO}_{2}$ レーザーによる穴 あけ法 ${ }^{2)}$ が生産現場に導入されつつある。

ここでは, 最先端プリント基板におけるレーザー加工の 必要性,および筆者等が開発しているプリント基板穴あけ 用 $\mathrm{CO}_{2}$ レーザーの発振器技術, 加工機シ，ステん, その加工例 について紹介する。
2. 最先端プリント基板における レーザー加工の必要性

電子機器の小型化 ·高機能化に対応してLSI化された チップ間の相互接続が問題となる。一昔前の基板では, LSI チップを樹脂でモールドし, ムカデの足状に出た接続ピン をソケットに挿入して素子間の接続を行うのが主流で あった。この場合パッケージのサイズが大きく,個々の素 子はLSI化により小さくしても, 回路基板全体としては大き なものになってしまう. 理想的には極力チップの大きさ から大きくすることなくチップ間の接続を行いたい.一 方で, メモリ, システムLSI等の高集積化により,一つの半 導体チップから数百ピン, さらに近い将来MPUでは 1000 ピ ンを越えるピン数を引き出す必要がある3). そのような要 求に対して回路基板（ドーターボード, マザーボード)との 接続を容易にするパッケージ技術としてFig.1に示すよう

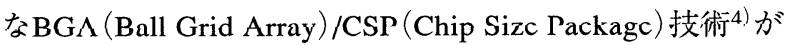
主流になりつつある。これらのパッケージ技術では多層 のパッケージ基板を介することにより,ピッチ $0.1 \mathrm{~mm}$ 程度 で形成されたチップ上の出力端子をBGAでは1.5〜 1.0mm に,また, CSPでは0.8〜0.5mm程度に変換し, 回路基板上で の素子間接続を可能とする. 


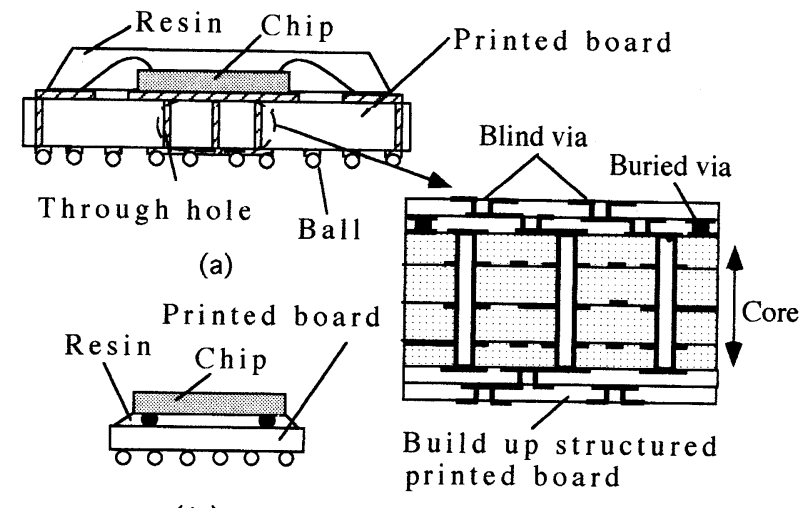

(b)

Fig.1 Construction of advanced packages of (a) BGA and (b) CSP.

さて, BGA/CSPで多ピン化が可能になるのは, 従来のよ うに周辺からだけではなく, 面全体の格子点から引き出せ るためである。一方で, $0.8 \mathrm{~mm}$ 以下のピッチで回路基板と の接続を実現するためには, 配線ピッチ $200 \mu \mathrm{m}$ 以下,さらに

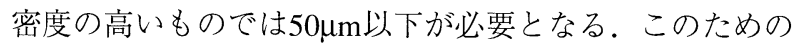
パッケージ基板の製作手法としてビルトアップ手法が主 流となりつつある。同手法ではコア材を中心層として メッキ,プリント等によって順次導体層, 絶縁層を積み上 げていく．各層の基板を作って一括して積層する従来の 方法に比べ, 配線密度を大幅に高めることができる。その 最大の理由は「レーザー法」の適用により微小径のベリード ビア(埋め込み穴), ブラインドビア(止まり穴)の形成が可 能となったからである. Fig.2にレーザー法によるビルド アップ基板加工プロセス例を示す．同加工は「ドリル」でも 可能であるが, コストが高くなり, 現実的な適用が難しかっ た。また,「フォトビア」による方法も一方で適用されてい るが, 樹脂材料として感光材料を使う必要があり,「レー ザー法」は材料に対する自由度が大きいことも大きな特徴

\section{Fabrication of base circuit}

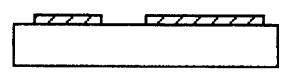

Formation of insulating resin

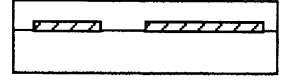

Laser drilling $\begin{aligned} & \text { Laser } \\ & \text { power }\end{aligned}$

\section{Copper plating}

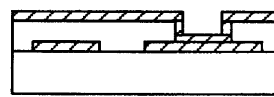

Via-hole

Etching

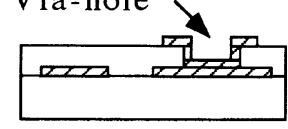

Fig.2 Example of production process of a built-up electric board by laser drilling.
である。

\section{3. プリント基㤆穴めけ用レーザー加工機}

3.1 プリント基板穴あけ用 $\mathrm{CO}_{2}$ レーザーの特徵 現状の電子基板ではエポキシ, ガラスエポキシ, ポリイ ミド等の材料が主流である.これらの材料に対し $\mathrm{CO}_{2}$ レー ザーで穴あけを行う場合, 従来の板金用レーザーに適用す るようなミリ秒からサブミリ秒オーダーのレーザーパル スを使った場合は, 穴周辺の炭化が多く基板として使用す

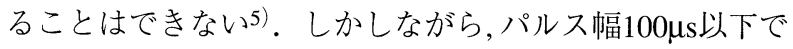

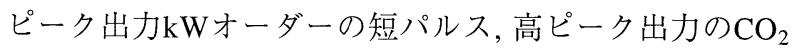
レーザーを照射した場合には,レーザービームを照射した 領域の周囲に熱伝導が起こる以前に局所的に樹脂材料が 溶融, 分解し, 材料が蒸発する過程で入射エネルギーの一 部も持ち去られる。このため加工穴周辺に対する熱影 響・炭化が少ない加工が可能となる。

$\mathrm{CO}_{2}$ レーザー光による加工では1パルス当たりの加工深 さ(エッチレート)は通常 $10 \mu \mathrm{m}$ 以上の值が得られる。一方, YAGレーザーの3倍，もしくは4倍高調波，エキシマレー ザー等の紫外線レーザー光では, 樹脂材料に対する吸収係 数が1桁以上高くなり, せいぜい数ミクロンオーダーしか深 さ方向に浸透できないため, エッチレートも数ミクロン以 下となる。この特性により $\mathrm{CO}_{2}$ レーザーは生産性・ランニ ングコストの面で有利となる。面, 集光性の面で30 $50 \mu \mathrm{m}$ の穴あけ径が限界と考えられ, 近い将来必要とされる $30 \mu \mathrm{m}$ 級の超微細な穴あけ領域では紫外線レーザーが導入 されると考えられている6).

\section{2 レーザー発振器}

プリント基板に適用される短パルス・高ピーク $\mathrm{CO}_{2} レ ー$ ザーとしてはTEA CO 2 レーザー7), 壁面冷却式スラブ型 $\mathrm{CO}_{2}$

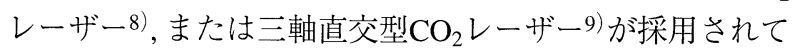
いる.しかしながら,これらプリント基板用レーザーの特 性に関しては極めて激しい競争が繰り返されている基板 業界にあって，ほとんど公表されていないのが実体であ る。以下では筆者等が携わるレーザー装置の技術概要に ついて紹介する。

\section{(1) 放電励起方式}

筆者等は, 板金加工用レーザーとして多くの実績を有す る無声放電 (Silent Discharge) 励起の三軸直交型 $\mathrm{CO}_{2} レ ー$ ザーを採用している ${ }^{9,10)}$ 。同方式の特長は以下の通りであ る.

(a) 高周波電源を変調することによりパルス幅を容易に 制御することができ, 加工材料に応じた短パルス・高ピー ク出力を発生できる.

(b)電極表面の誘電体バリアーにより放電電流の均質 化・放電安定化を図ることができ, $\mathrm{kHz}$ オーダーでの安定 した繰り返し動作が可能となる。

発振器の電極構造をFig.3に示す。金属パイプの外周に 誘電体をコーティングした電極を対向配置し,両電極間に 交流高電圧を印加する．軸流ブロワと熱交換器からなる 


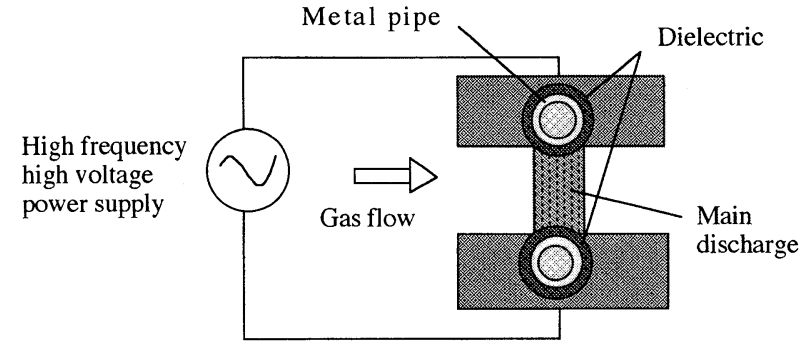

Fig.3 Cross-sectional view of excitation region of silentdischarge excited $\mathrm{CO}_{2}$ laser.

ガス循環系により冷却されたレーザーガスを放電部に流 し込んでいる。

高ピーク出力発振を実現するためには必要なピーク出 力よりほぼ 1 林高い瞬時電力を投入する必要がある. 無声 放電励起 $\mathrm{CO}_{2}$ レーザーにおける放電電力は以下の式によっ て表される.

$$
W_{\mathrm{d}}=\pi f C_{\mathrm{g}} V^{*}\left(V_{\mathrm{op}}^{2}-V^{2}\right)^{1 / 2}
$$

ここにおいて $C_{\mathrm{g}}$ : 電極の静電容量, $f$ : 電源周波数, $V^{*}$ : 放電電圧波高值, $V_{\mathrm{op}}$ : 印加電圧波高值である. $C_{\mathrm{g}}$ は誘電体 材料の誘電率, 絶縁耐力, 放電面積で決まるもので, それ程 大きな自由度はない. $V^{*}$ はガス混合比, ガス圧力, および 出力ビームを取り出すのに必要な放電ギャップ長で決ま る.ピーク電力の増大は主にガス圧力増大による $V^{*} の$ 増 大, および励起電源の高周波化により実現している。従来 のプリント基板用のレーザーでは数百 $\mathrm{kHz}$ の電源でパルス

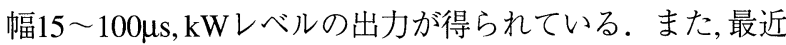
開発した装置ではMHzまで電源周波数を増大しパルス幅1

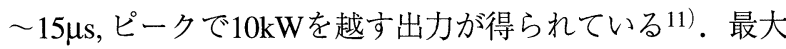
繰り返し周波数は $4 \mathrm{kHz} ゙$ あ.

Fig.4は電極間に印加される電圧, 放電電流とレーザー出 カとの関係を示している.

高周波電圧を電極間に印加した後ある遅れ時間を経た 後にレーザー光が立ち上がる。この際のレーザー発振の遅 れは, (a) 放電エネルギーが $\mathrm{N}_{2}(\mathrm{v}=1)$ から $\mathrm{CO}_{2}(001)$ に移乗 され, 利得が発振しきい值に達するまでの時間, および (b) 利得がしきい值に達した後にレーザー光が飽和強度のレ ベルに達するまでの時間により決定される。また,レー

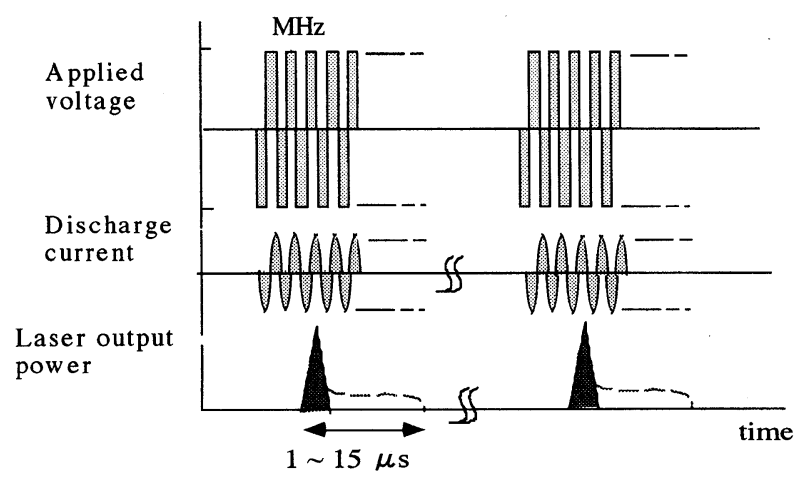

Fig.4 Relation of waveforms of an applied voltage between main electrodes, a discharge current and a laser output power. ザー光が立ち上がるまでの遅れ(b)により, 利得はその間に しきい值を越えていわゆるゲインスイッチングを生じ, レーザー光立ち上がり時には高ピーク出力 (ファーストス パイク)が発生する. その後に放電励起密度に応じた準定 常的な発振が得られる。この領域では放電励起時間を制 御することによりパルス幅を最適な值に制御することが できる。

\section{(2) $\mathrm{MHz}$ 動作高周波電源}

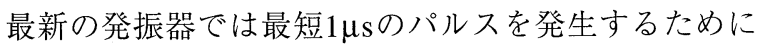
$\mathrm{MHz}$ の高い周波数で動作する高電圧電源を開発してい る. その回路図をFig.5に示す。従来の交流高圧電源では 200４00Vの交流電圧を高電圧トランスによって昇圧し, 高電圧化するのが一般的である。しかしながら,このよう な電源に対して今回の放電負荷を接続した場合, 昇圧トラ ンスにおけるリーケージインダクタンスが大き過ぎるた めに, $\mathrm{MHz}$ の高周波動作時に必要な放電電流を流すことが できないことが問題となる。このため, 直流高電圧 $(6 \mathrm{kV})$ をMOS-FETにより直接スイッチングして交流高電圧を取 り出す電源 (ダイレクトスイッチング方式トランスレス高 周波電源)を開発した。この結果MHzによる高電力密度励 起において短パルス・高ピーク出力発振を実現するとと もに $1 \sim 15 \mu \mathrm{s}$ の範囲で自由な発振パルス幅の制御を可能と している.

\section{3 加工機システム}

プリント基板用レーザーと組み合わされたプリント基 板加工機システムの構成をFig.6に示す。また, Table 1に加 工機系の性能を示す。加工光学系はマスク形状をワーク 上に転写する縮小転写光学系となっている。加工の穴径

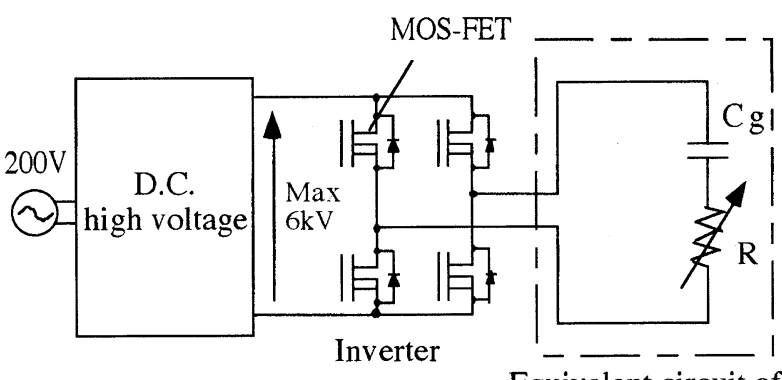

Equivalent circuit of discharge load

Fig.5 Circuit diagram for a high frequency power supply.

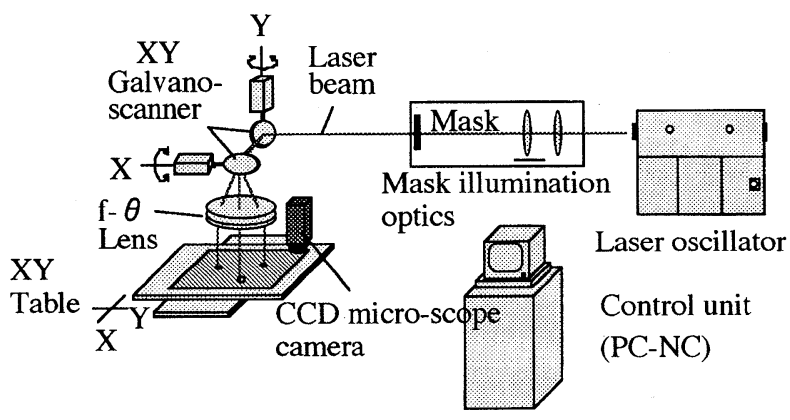

Fig.6 System diagram of micro-drilling processing unit with a high-peak power $\mathrm{CO}_{2}$ laser. 
Table 1 Performance characteristics of a work table necessary for micro-drilling by a high-peak power $\mathrm{CO}_{2}$ laser.

\begin{tabular}{|c|c|c|}
\hline & Term & Specification \\
\hline $\mathrm{X}-\mathrm{Y}$ & Work area $(\mathrm{mm})$ & $620 \times 510$ \\
\hline \multirow[t]{4}{*}{ table } & Maximum feed speed (m/min) & 90 \\
\hline & Positioning accuracy $(\mathrm{mm})(\mathrm{X})$ & $0.005 / 620$ \\
\hline & $(\mathrm{Y})$ & $0.005 / 510$ \\
\hline & $\begin{array}{l}\text { Repetitive positioning accuracy } \\
\text { (mm) }\end{array}$ & \pm 0.002 \\
\hline \multirow{4}{*}{$\begin{array}{l}\text { Galvanic- } \\
\text { scanner }\end{array}$} & Scanning area $(\mathrm{mm})$ & $50 \times 50$ \\
\hline & Positioning speed (point/sec) & 800 \\
\hline & Positioning accuracy (mm) & \pm 0.020 \\
\hline & $\begin{array}{l}\text { Repetitive positioning accuracy } \\
\text { (mm) }\end{array}$ & \pm 0.010 \\
\hline $\begin{array}{c}\mathrm{Z} \text { axis } \\
\text { stroke }(\mathrm{mm})\end{array}$ & & 80 \\
\hline
\end{tabular}

は転写光学系のマスクをオートチェンジャーで交換する ことによって変化させる. 収束性の高いTEM $\mathrm{T}_{00}$ モードビー ムと比較的大きな集光 $N A$ を有する転写レンズを採用する ことにより, 最小 $\phi 50 \mu \mathrm{m}$ までの微細穴加工に対応できる水 準にある。

2軸のガルバノミラーと大口径の $f \theta$ レンズをよってワー ク上 $50 \mathrm{~mm} \times 50 \mathrm{~mm}$ のエリアをスキャンする．生産性向上 の観点からガルバノミラーの高速化に対する要求は大き い. 最近では微細集光に適した大口径のスキャンミラー を用いながら, $800 \mathrm{~Hz}$ という高速の位置決め速度が実現さ れている。テーブル移動と組み合わせて $\square 50 \mathrm{~mm}$ の領域を ステップアンドリピート方式で加工し, 基板全体の穴あけ を行なう。

$\mathrm{CCD}$ 顕微鏡カメラは, 基板上のアライメントマークを画 像処理によって認識し, ワークをテーブル上にセットする 際の位置・角度ずれ, およびワークの伸縮誤差を補正す る. また, 実際に穴加工を行い, 同カメラを用いて校正す ることによって, 2 軸スキャンでは不可避的に発生する $f \theta レ$ ンズの非線形性などの光学系の誤差の補正も行なってい る.

\section{4 ビーム強度分布の制御による大口径加工特性の} 改善

レーザー法は先にも述べたようにブラインドビアーを 形成できることが大きな特長である。このため，もともと $\phi 150 \mu \mathrm{m}$ 以下の微細穴あけへの適用を意図した技術であっ たが, $\phi 300 \mu \mathrm{m}$ 程度の大口径ブラインドビアーを形成する要 求も増えつつある。

大口径の加工ではビーム照射面積が大きいため, 転写マ スクにおける開孔径が大きくなり, シングルモードのビー ムを照射した場合には, 必然的に中心部分が強い分布とな る。このビームをワークに照射すると,穴の中心において 内層銅箔にダメージを与えることがある。これを回避す るために, ビーム強度分布を任意に変換するレンズを開 発12) ${ }^{12}$, 照射ビーム強度分布の均質化を図っている。強度 分布を変換した場合と変換しない場合の加工結果を各々 Fig.7 (a)，(b)に示す．同図より強度分布の均質化により大

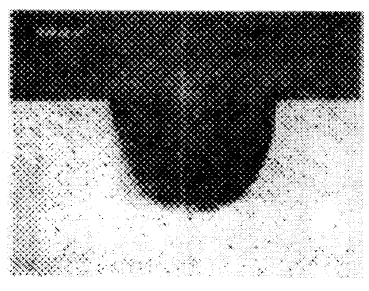

(a)

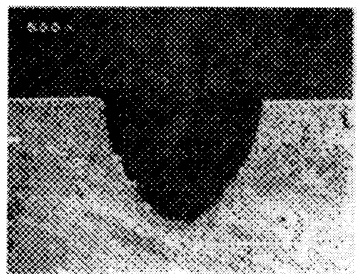

(b)
Fig.7 Comparison of processing results (a) with a beam homogenizer and (b) without a beam homogenizer.

口径の穴あけにおいて, 底面がフラットな加工ができるこ とがわかる。

\section{4. プリント基板加工例13)}

従来筆者等はパルス幅 $15 \sim 100 \mu \mathrm{s}$, ピーク出力 $\mathrm{kW}$ レ゙ル のレーザー発振器を使ってプリント基板加工を行ってき

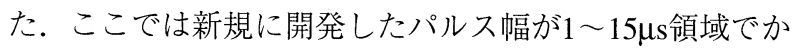

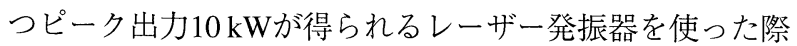
の特徵的な加工結果について紹介する.この出力領域は いわゆるTEA $\mathrm{CO}_{2}$ レーザーよりもパルス幅的には1桁長く, また, ピーク出力的には1桁低い, 従来にはない加工領域で ある。

4.1 エポキシ樹脂への微細穴あけ $(\phi 50 \mu \mathrm{m})$ 加工例

Fig.8 (a)，(b)に銅䇴を内層したエポキシ系樹脂に対して $\phi 50 \mu \mathrm{m}$ のバイアホール加工を行った場合の結果を示す．樹 脂の厚み $50 \mu \mathrm{m}$, 内層銅箔の厚みは $35 \mu \mathrm{m}$ である。(a), (b) は 各々パルス幅が $8 \mu \mathrm{s}, 48 \mu \mathrm{s}$ の結果である．ピーク出力の観点 からは, (a)の結果は (b)に対し6倍高いピーク出力を照射し ていることになる。

微細穴 $(\phi 50 \mu \mathrm{m})$ の加工の場合, 加工穴周辺におけるダレ を防ぐために必然的に照射エネルギーを低く抑える必要 がある.この時内装銅箔が厚い $(t=35 \mu \mathrm{m})$ 場合, 銅箔を十 分に加熱できず,その表面に樹脂残りが起こりやすい. 樹 脂残りが多いとプリント基板製作時に電気的な接続不良 を引き起こし,問題となる．8 ス・高ピーク出力効果により銅泊部分にレーザー照射エ ネルギーが熱伝導される前に樹脂部分が溶融・蒸発し, 内 層銅箔の厚みにあまり関係なく樹脂残りを低減できるこ

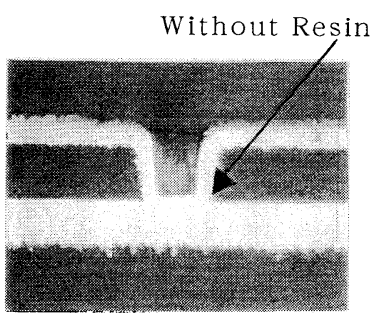

(a)

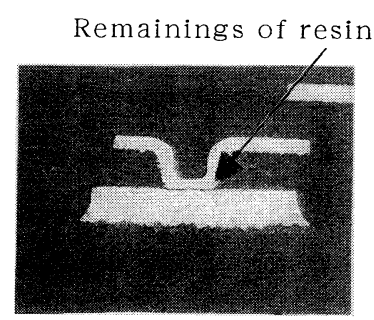

(b)
Fig.8 Results of micro-drilling of epoxy material with a diameter of $50 \mu \mathrm{m}$ by a laser beam with a pulse duration of (a) $8 \mu \mathrm{s}$ and (b) $48 \mu \mathrm{s}$. 


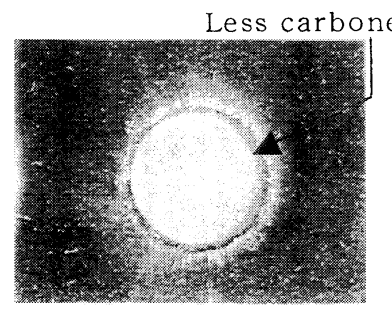

(a)

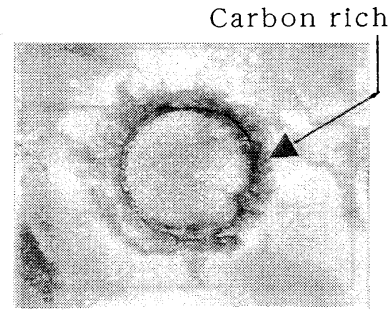

(b)
Fig.9 Results of micro-drilling of polymid material with a diameter of $300 \mu \mathrm{m}$ by a laser with a pulse duration of (a) $8 \mu \mathrm{s}$ and (b) $48 \mu \mathrm{s}$.

とが確認される。

4.2 ポリイミドの大口径穴あけ $(\phi 500 \mu \mathrm{m})$ 加工の例

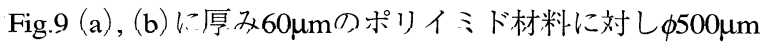
の穴あけ加工を行った際の結果を示す。（a）はパルス幅 $8 \mu \mathrm{s},(\mathrm{b})$ はパルス幅 $48 \mu \mathrm{s}$ の結果である。従来大口径の穴加 工を行う際には, 必要なエネルギーを与えるためにパルス 幅を長く設定する $(\sim 50 \mu \mathrm{s})$ 必要があった。結果として Fig.9(b)に見られるようにポリイミド樹脂の炭化が多くな り加工直後の穴壁面に炭化物が付着するという問題が生 じていた.また, 穴周辺への熱影響も多くなる傾向も見ら れた。今回, 同一パルスエネルギーでパルス幅の短いパル スを照射した結果, Fig.9 (a)に見られるように穴壁面にお ける炭化物発生量を減少することができた。短パルス化 により熱伝導領域を抑制した効果と考えられる。

\section{3 ガラス基材入り基板の加工例}

大口径のガラスエポキシ樹脂の加工ではガラスを溶融 する必要から, 入射エネルギーを高く設定する必要があ る. 例えば, 厚さ $100 \mu \mathrm{m}$, 穴径 $\phi 300 \mu \mathrm{m}$ のブラインドホール の加工例では, 銅箔が薄い場合 $(t=18 \mu \mathrm{m}$ 以下 $)$ は銅箔に損 傷し易いという問題があり, $48 \mu \mathrm{s}$ の結果では銅箔部に損傷 が生じている．8 4 sに設定した場合は, 短い時間内に溶融・ 蒸発に必要なエネルギーを与えることができるため,この ようなガラスエポキシ樹脂の大口径加工においても銅䇴 部に損傷を与えることなく高品質の加工ができることが 確認された。

\section{5. おわりに}

最先端プリント基板におけるレーザー加工の必要性, お よび筆者等が開発したプリント基板穴あけ用 $\mathrm{CO}_{2}$ レーザー の発振器技術, 加工機システム, その加工例について紹介 した.

板金加工において実績のある無声放電励起部に対して ダイレクトスイッチング方式トランスレス高周波電源を 適用することにより, パルス幅 $1 \sim 15 \mu \mathrm{s}$, ピーク出力 $10 \mathrm{~kW} の$ 発生を可能とした.この出力領域は従来のパルス $\mathrm{CO}_{2}$ レー ザーでは得られない新規の動作領域であると考えられ る。基板加工に適用した結果では, 銅一エポキシ積層基板

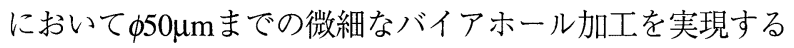
と共に, ポリイミド,ガラスエポキシ基板における大口径 穴加工においても照射条件の最適化により高品質加工が 実現できるここが実証された。

$\phi 150 \mu \mathrm{m}$ 以下の微細な穴あけ加工の分野では短パルス · 高ピーク出力 $\mathrm{CO}_{2}$ レーザー加工機が急速にラインに導入さ れつつあり, 今後さらなる生産性向上, 高品質加工に向け たハード,ソフト面での開発を続けていくことが必要であ る。また, $\phi 50 \mu \mathrm{m}$ 未満の穴あけ領域ではYAGの3倍高調波, もしくは4倍高調波による加工が今後適用されると考えら れ, これらレーザーの高出力化, 高信頼化に向けた技術開 発が急速に発展することが期待される.

\section{参考文献}

1）堤 章, 有光義雄: 電子材料9月号 (1998) p.33.

2) 水野正紀, 福島司, 金岡優, 西前順一, 今井祥人, 竹野祥瑞: 三菱電機技報 71 (1997) 395 .

3）朝倉博史：日経マイクロデバイス12月号 (1996) p.139.

4) 春日 壽夫編著：表面実装ポケットブック超小型パッケージ CSP/BGA技術（日刊工業新聞社, 1999) p.14.

5) 岡村 寿郎: 電子材料5月号別冊 (1999) p.32.

6) 木内 浩：電子技術6月号別冊 (1999) p.88.

7) 礒圭二：電子材料10月号 (1996) p.101.

8) 永井治彦：レーザー研究 27 (1999) 156.

9) 葛本昌樹, 竹中祐司, 田中正明, 竹野祥瑞, 森安 雅治, 平本 誠 剛：レーザー研究 19 (1991) 901.

10）西前順一, 暮本昌樹, 福島司：レーザー学会研究会報告 RTM98-2 (1998).

11）佐藤行雄, 西前順一, 岩田明彦, 竹野祥瑞, 福島司, 金岡優： レーザー熱加工研究会誌 6 (1999) 28.

12）松原真人, 竹中祐司, 西前順一：レーザー学会学術講演会第 18回年次大会予稿集 (1998年1月) p.153.

13) 湯山崇之, 廣崎達也：第44回レーザ熱加工研究会論文集 $(1998$ 年7月) p.89.

\section{レーザーワード}

\section{微細穴あけ加工 (micro-hole drilling)}

携帯電話, デジタルムービー, 携帯パソコン等, 近年電子 機器の超小型化, 高機能化にともない電子基板の多層化 · 高密度実装化が急激に進んでいる．これら多層電子基板 製作に必要な高密度性と生産性が両立できる穴あけ加工 技術.

従来直径 $200 \mu \mathrm{m}$ 以上の穴あけでは機械的なドリルにより
対応してきたが, 最近の基板の主流である $150 \mu \mathrm{m}$ 以下の領 域ではレーザー法，またはフォトビア法が導入されてい る. 現状直径 $50 \mu \mathrm{m}$ 領域まで実用化の域に達しつつあるが, さらに数年後には $30 \mu \mathrm{m}$ 級の穴あけ加工が必要とされる.

(佐藤 行雄) 